\title{
Introduction: Encounters between Trauma and Ekphrasis, Words and Images
}

\section{Central themes}

This book seeks to question a juncture, or crossing, between two different discourses or fields of investigation: trauma and ekphrasis. It responds to the recognition that terrorizing images permeate the public sphere in connection with traumatic experiences and conflicts and emphasizes the ways in which such images are described and interpreted in words. Its main intention is to analyze the incorporation of verbally represented images - mental images, media images, and artistic images - in literary texts and to discuss their form and function. The importance of images in the context of political conflicts has been scrutinized in recent criticism, but scholarly attention to their verbal representations is less widespread. This book argues that an examination of the concept and practice of ekphrasis is crucial to understanding how the images in question work and that a foregrounding of their diverse effects and functions in contemporary literature is vital for illuminating and understanding such images.

Contemporary literature is analyzed here in the context of its engagement with visual culture in a broader present-day and historic perspective. The interpretations demonstrate how literature provides a meeting place between trauma and the visual image. Rather than scrutinizing this encounter as though it were exclusively the object of visual or cultural studies, we emphasize the specificity of the literary engagement with visual images. This entails neither jettisoning the traditional concept of ekphrasis, typically defined as encompassing "a verbal representation of a visual representation" (Heffernan 2004: 3), nor uncritically reproducing its traditional function, but rather subjecting it to scrutiny and, where necessary, to displacement. The force of this displacement can in part be observed in how contributors seek new turns of phrase - such as "ekphrastic inversion," "speculative ekphrasis," and "phantomogenic ekphrasis" - to describe the ekphrastic dimension of the texts interpreted. As the contributions to this volume will show, a traditional interpretation of ekphrasis as also encompassing a wider field of engagement, including pictorial energeia, also underlines how the concept suffers transformation as it travels into new historical and discursive zones.

One might construe ekphrasis as a conceptual dinosaur from an earlier age, when literary analysis had yet to face any real challenge from visual studies or 
cultural studies. Yet W. J. T. Mitchell has warned against the construction of simplistic historical narratives whereby, for instance, there is "a single 'great divide' between the 'age of literacy' [...] and the 'age of visuality.' These kinds of narratives are beguiling, handy for the purposes of presenting polemics, and useless for the purposes of genuine historical criticism" (Mitchell 2005: 349). Rather than looking at ekphrasis as a dated, exclusively literary approach, it would be more generous to view it as a trailblazer for later approaches to intermedial and multimodal forms of expression. Critical and literary engagements with ekphrasis were pioneering efforts to engage with the kinds of crossing of borders that are now among the central concerns of the humanities.

Seen from the perspective of literary studies, ekphrasis also has the benefit of not jettisoning the text for some frictionless multimedial space. This does not, however, entail that the earlier conceptions of ekphrasis can be accepted wholesale without reformulation. Early attempts to formulate how ekphrasis works concentrated almost exclusively on the relationship between word and image. The relationship between literature and painting was endlessly deliberated upon, their close but difficult relationship understood as one between "sister arts" (as in Hagstrum 1958), or even as a fraught but productive love affair. The temptation was to present them as natural opposites in an ineluctable binary. The identification of literature with temporality and the visual arts with spatiality, encouraged by Lessing's Laocoön essay (2003 [1766]), was key to the emergence of this conceptual dyad. Once they are presented together in this way, the two art forms quickly accrue other, metaphysical properties. In particular, the image becomes the carrier of spontaneity and presence, and ekphrasis becomes invested with a desire - or "hope" in W. J. T. Mitchell's formulation - to somehow allow the verbal medium to appropriate these qualities (see Mitchell 1994: 152156). Coming as a belated supplement to the preceding image, the verbal performance tries to usurp the primacy of the visual.

Conceptualizations of the ekphrastic relation between text and image have been subject to historical change and are not built on natural or essential determinations. Yet the idea that visual images are somehow more direct and vital recurs and is perhaps also an inescapable part of the conceptual heritage of ekphrasis. From this perspective, literature's engagement with the visual is either a way in which literature can escape the confines of its own medium, or, more humbly, a means to revitalize our sensual engagement with the world. Subjected to a simultaneously defamiliarizing and deciphering gesture, obfuscating mechanisms give way to redemptive clarity. William Wordsworth wrote of poetry's need to show the extraordinary in the ordinary, and ultimately the wish to get beyond conventional barriers in order to gain access to vital immediacy is a Romantic one (Wordsworth 2012). Maurice Blanchot used a reading 
of Friedrich Hölderlin to identify literature's desire for a spontaneous form of speech (Blanchot 1995: 111-131), and Geoffrey H. Hartman (1954) did the same in Unmediated Vision. The paradox here is that literature borrows the idiom of another medium in order to attain an unmediated condition. Does this mean that literature creating a false sense of immediacy? An important tenet of contemporary visual culture studies is that "the idea of the visual object cannot be reduced to codes and signifying systems" (Moxey 2008: 138). If literature is inherently bound to semiotic codes alien to the image, then its dealings with visuality may merely be paying lip service to an impossible ideal.

The opposition between word and image may, however, be a potentially limiting one, and we may have much to gain by opening it up or going beyond it. In On Certainty, Wittgenstein humorously tries to encapsulate what he sees as the absurd consequences of a particular philosophical tradition in a brief anecdote: "I am sitting with a philosopher in the garden; he says again and again 'I know that that's a tree', pointing to a tree that is near us. Someone else arrives and hears this, and I tell him: 'This fellow isn't insane. We are only doing philosophy" (Wittgenstein 1969: 61e). What Wittgenstein satirizes here is the understanding of language as primarily referential, involving the subject in a verbal imitation of sensory objects. Wittgenstein's riposte to this view can be found in a parallel sketch, presented early on in his Philosophical Investigations, of a group of builders erecting a wall. Wittgenstein's imagining of a primitive language that "is meant to serve for communication between a builder A and an assistant B" demonstrates that it is not enough to have names for the various tools employed by the builders: one also needs to be able to communicate how to employ those tools in the actual building process (Wittgenstein 1958: 3). The example entails moving from designative, subject-object relations (as in the pointing at a tree, or the naming of a tool) to an understanding of words as means to get a job done. One way to frame this is to say - as J. L. Austin and his followers indeed would - that Wittgenstein wants to replace a constative view of language with a performative one. One might go further and claim that he risks reducing language's role to a depressingly narrow utilitarian function. A different way of looking at this, however, would be to emphasize the fact that the builders are essentially placed within a context. The words they utter are not only intended to have an effect on their surroundings - they can and do, in fact, have such an effect.

One might speak of the event of ekphrasis, or - as Hans Lund already did in the 1980s - of “contextual ekphrasis." Lund's article focuses on how a poem by Swedish writer Birgitta Trotzig dealt not only with a sculpture by Bernt Notke but also with the surrounding environment of St. Nicholas's Cathedral in Stockholm (Lund 1998: 179-187). There is a parallel here to the highlighting of the role of 
the museum in ekphrasis by such scholars as James Heffernan (2004), Catherine Paul (2002), and Barbara K. Fischer (2014). The institutional role of the museum both as a precondition for the distribution and the availability of artworks in the period after 1800, and the actual role of museums as a crucial motif in literary texts dealing with the visual arts, should not be underestimated. The museum is not a static background or setting for the act of ekphrasis but affects all the elements of the process. Jonathan Culler illuminates this point, by making a helpful conceptual distinction:

[...] one might try to think not of context but of the framing of signs: how are signs constituted (framed) by various discursive practices, institutional arrangements, systems of value, semiotic mechanisms? [...] Although analysis can seldom live up to the complexities of framing and falls back into discussion of context, with its heuristically simplifying presumptions, let us at least keep before us the notion of framing. (Culler 1988: ix)

To think of a frame rather than a context enables us, in Culler's view, to take seriously the constitutive role of the underlying preconditions that surround cultures and make possible cultural expressions.

The essays in this volume investigate how extreme political, cultural, or psychological frameworks affect the use of ekphrasis. World War I, the Stalinist Terror, the Spanish Civil War, World War II and Auschwitz, the Vietnam War, the Northern Irish Troubles, the Bosnian War, the AIDS crisis, 9/11, and impending natural catastrophes are all addressed. Such grueling conflicts and catastrophes are indeed more than mere contextual background material. They act as implacable interpellations that demand our attention. They involve suffering on a scale hard to fathom and demand an immediate political or ethical response from literature and the arts. Yet even such disasters require interpretation rather than immediate visual responses or simply mimetic acts of witnessing.

These events can all be approached in terms of the paradigmatic narrative of trauma, even as all give that narrative their own unique inflection. If trauma has "created a new language of the event" (Fassin and Rechtman 2009: 6), the idiom of that language changes subtly, depending upon which historical occurrences are being formulated in it. Certainly, World War I, the concentration camps, the Vietnam War, and the sexual politics of the 1990s have played important roles in the articulation of the concept of trauma, even if the first modern uses of the term to denote mental rather than physical damage date back to nineteenth-century railway accidents (Luckhurst 2008: 22-26). Trauma provides a particularly influential and powerful conceptual framework that has steadily been accruing a dominion of its own. There is, of course, a danger that it will become a myth or naturalized ideology: the master narrative of trauma becomes vulnerable, in such a case, to being accused of being an arbitrary codification of 
more or less indifferent empirical data. Diagnostic language and modes of explanation may, in such cases, appear oppressive and alienating to suffering individuals. Contemporary worries about the heterogeneity of the illnesses that are labelled as traumatic suggest that the widespread embrace of the concept has come at the price of empirical precision (see, for instance, Morris 2016: 13). One could also cite the work of Stef Craps (2013) and others on the Western inflection of the trauma paradigm. The latter developments have, however, led to a revision and expansion of the notion of trauma, making sure it also can address long-term, 'insidious' forms of violence such as colonial oppression.

If trauma is a fuzzy concept, and is subject to processes of revision and negotiation, it is nonetheless a framework that lends itself well to a two-way dialogue with ekphrasis. The two phenomena are closely related. The deferred manifestation, or Nachträglichkeit, of trauma is akin to the temporal lapse that typically occurs between the ekphrastic image and its verbal response. In addition, the visual element of ekphrasis essentially connects with the traditional conception of trauma as associated with particularly harrowing mental images. Ekphrasis becomes a literary mediation of the act of witnessing. At the same time, the concept of ekphrasis is arguably subjected to modification in the process. This is evident in the cases in this book where the visual image that the literary texts respond to is of a distinctly mental kind. This points to the need to broaden our understanding of ekphrasis so that the term encompasses not only objects or artworks but also a kind of mimesis of the traumatized mind. Ruth Webb's (1999) unearthing of how, in Greek antiquity, the term referred not only to responses to objects but also to a wide variety of phenomena (including actions) is productive in this regard, particularly because Webb interprets ekphrasis as enargeia, a vivid, picture-like description of a given. Thus, Heffernan's exclusion of pictorialism from the definition of ekphrasis is here challenged (Heffernan 2004: 3). Thanks to trauma, a wider understanding of ekphrasis, responding to a broader range of phenomena, becomes possible.

Terrorizing images have become more relevant than ever in light of the current conflation of worldwide terrorism and the new, digital articulation and proliferation of images. This situation leads to changes in how human communities and politics are constructed. While the use of new digital technology has expanded a global network of information, it has also fed parochialism, the "battle of civilizations" hypothesis, and nationalist upsurges such as Brexit and Trump's election victory. The idea of community is arguably in a particularly fragile state. The essays in this volume highlight this in various ways.

The role of the spectator is a contentious one. The ethics of spectating, and the inherent danger of voyeurism, may be described as an ineluctable problem especially characteristic of our contemporary age. This book addresses litera- 
ture's engagement with a range of such practices, including video art, photography, and digital media. W. J. T. Mitchell's idea of the extreme "cloning" power of the digital media articulates how the very idea of images is being changed in a way that pushes Walter Benjamin's argument (1968: 217-252) regarding the age of reproduction to a further extreme. As digitalized images take on "a perverse life of their own" (Mitchell 2011: 99), the concept of the image is being changed into something characterized by extreme flux. Does the volatility of the image allow it to eventually stabilize, or does it rather expose a radical instability in which diverse interpretative frameworks are revealed to be only provisional, and potentially conflicted, heuristic devices? A layering of multiple images is a feature of many of the readings of this volume. If both collective and individual trauma are characterized by complex processes of memory, one of the ways in which that complexity becomes evident is through a staggering multiplicity of images.

Several contributors make use of psychoanalytical theory in their chapters, which, perhaps, is no surprise given the importance Freud ascribed to processes of repetition and transformations of psychic content. The Freudian paradigm's deployment of a therapeutic discourse in the analyses of literature and trauma is, however, not uncontroversial. Post-structuralist theory insists that the complexity of the literary text makes it irreducible to unequivocal determination, and therefore also not easily instrumentalized as a vehicle of catharsis. The chapters of this book view the novels, plays, and poems they address as more than simple addenda, trailing the force of the images that preceded them. The literary texts help us see and interpret the terrorizing images. Yet they are not simple instruments of catharsis, as they can also both prolong and reinvest the impact of those images. This ambiguity is essential to literature, and it is one of the reasons literature does not easily lend itself to straightforward instrumentalization and other acts of pigeonholing. Like the visual image, the verbal art is ultimately resistant to reduction.

\section{The chapters}

The opening chapter by Frederik Tygstrup takes as its point of departure Susan Sontag's and Judith Butler's discussions of photographs of war and human suffering to explore a political space from which terrorizing images can be assessed. His selected case study is Peter Weiss's novel The Aesthetics of Resistance (1975), which opens with a lengthy ekphrastic enactment of an encounter with the Pergamon altar, detailing the suffering and atrocities displayed on the frieze. As the description's reference is not immediately disclosed, Tygstrup suggests that it 
paradigmatically demonstrates how a particular triangle of representation - the sacrosanct work of art, the worthy object, and the delectating beholder - needs to be broken up in order to reframe the affect and become responsive to it.

A recent novel by Don DeLillo is the topic of Øyvind Vågnes' subsequent chapter. He discusses Zero $K$ (2016), where the protagonist arrives at a fictional facility, The Convergence, which specializes in extending life through cryonic freezing. Walking the corridors of The Convergence, he is confronted with silent footage that appears on screens that are lowered from the ceiling, all of which show scenes of devastation and destruction. Vågnes argues that Zero K's ethical urgency derives from the book's central tension between two different body images: the precarious bodies of the footage and the bodies cryonically preserved. A critique of the basic tenets of posthumanism, DeLillo's speculative fiction pits cyber-fantasies of radical disembodiment and transcendence against imagery that evokes the uncanny, in the process questioning our sense of humanity in the era of the Anthropocene.

How can we understand the desire for trauma in our society, and what are the links between trauma and intermediality and between trauma and intertextuality? In chapter 3, Joachim Schiedermair discusses these questions together with Johan Harstad's play Etc. (2010) and his novel Max, Mischa \& the Tet Offensive (2015). He argues that ekphrasis, on the one hand, functions as a transformation of a (mental, artistic, or documentary) picture into text (i.e., into a different medium). On the other hand, although trauma can be described as an uncontrollable recurrence of the same images, the context in which these images occur is subject to change. The identity of traumatic images and their tendency to be subject to mobility and transformation can therefore be analyzed as an intertextual phenomenon in trauma literature: as travelling images (akin to Mieke Bal's (2002) concept of “travelling concepts") moving through a number of texts.

Two of the contributions examine novels by Michael Cunningham. Unni Langås's chapter is a reading of The Hours (1998), which echoes not only Virginia Woolf's Mrs. Dalloway (1925) but also Sigmund Freud's Beyond the Pleasure Principle (1920). From Woolf's post-WWI novel, Cunningham picks up the motif of trauma-ridden suicide and re-inscribes it into the character of an HIV-positive author at the end of the twentieth century. Cunningham repeats the idea of trauma as a return of images in individuals, but his novel is also a repetition of images, understood as ekphrastic descriptions and intertextual dialogue with literary references. Langås's reading emphasizes how the acute crisis of the novel's AIDS context turns the haunting images of the past into terrorizing anticipations of the future.

In chapter 5, László Munteán compares Michael Cunningham’s novel Specimen Days (2005) with Don DeLillo's novel Falling Man (2007) on the basis of the 
techniques they employ to represent images of the New York 9/11 jumpers. While ekphrasis, in the traditional sense, relies upon the imagination of readers to achieve its purpose, the kind of ekphrasis examined by Munteán builds on readers' memories of a particular event. Owing to the traumatizing nature of these events, such as the sight of people jumping out of the burning World Trade Center towers, visual documents thereof have been repressed and censored. Employing Nicolas Abraham's notion of the phantom, Munteán develops the concept of phantomogenic ekphrasis to address the oblique memory of these tabooed images, highlighting how the process of recollection in this text takes place without direct description.

In the sixth chapter, Adriana Margareta Dancus focuses on Édouard Louis's novel Histoire de la violence (2016), where the author recounts his own embodied experience of being physically and sexually assaulted. Louis mobilizes a variety of narrative voices and images to reconstruct what happened over the course of twenty-four hours, embracing the events before, during, and after the rape. Dancus shows how Louis reanimates a traumatic past in order to reclaim his story from forensic, medical, and judicial discourses. The author turns the tables not on the rapist but on the friends who pushed him to report the assault to the police, on the medical staff who objectified his personal trauma through the scientific gaze, and on the police, who asked him to recount the traumatic episode innumerable times and archived his story in a racially charged fashion.

Taking poems, prose vignettes, essays, short stories, and novels about the siege of Sarajevo by Semezdin Mehmedinović, Miljenko Jergović, Alma Lazarevska, and Mira Otašević as his point of entry, in chapter 7, Stijn Vervaet explores the relationship between war photography, ekphrasis, and memory. He examines how the writers reflect upon war photographs by international and local photographers, how and why they read the highly aestheticized work of Bosnian war photographers as an alternative to the media images produced by international war reporters, and how they describe images of war - both "mental images" and "real" war photographs. By embedding images of war in a literary discourse, these authors not only explore the tension between empathy and war photography but also aim to give back agency to those portrayed. They also seem to suggest that the alliance between literature and a specific type of war photography can help to create a counter-memory of the siege of Sarajevo.

Media images can be fundamentally manipulated by political interests, a historic phenomenon that Sinéad Morrissey addresses in her poem "The Doctors" (2013). In chapter 8, Charles I. Armstrong discusses how the poem casts critical light on the Soviet practice of "desecrating photographs," including those of undesirable or suspicious individuals, which was widespread during the more repressive period of the Soviet Union. Armstrong explores how Morris- 
sey's text casts poetry in the role of a kind of remedial intervention, suturing the wounds inflicted by the mismanaged "doctoring" of state propaganda. As a work of ekphrasis, he demonstrates that "The Doctors" has an ambivalent relationship to the paragonal tradition. For even though the poem presents an ethical lament to the erasure of the visual image, in some respects - as a work of literature, rather than a visual representation - it cannot help but prolong or even further that erasure.

The Troubles of Northern Ireland have been addressed in many works of fiction. Stephanie Schwerter's contribution - in chapter 9 - focuses on Mary Costello's novel Titanic Town (1992), in which the experience of political violence is rendered from a juvenile perspective. Set in Belfast in the early 1970s, Titanic Town illustrates the traumatizing influence of civil war on the development of young people. Her analysis is based on the concept of "mental maps," which have become one of the key references in contemporary urban studies. Schwerter explores the different ways in which Costello attempts to depict war-torn Belfast through the protagonist's mental images of her urban environment. She investigates how mental images are incorporated into the narrative of the story and how those images portray the city of Belfast as a place of conflict and tension.

One of the main areas of trauma research is the Holocaust, which Christine Berberich discusses in her reading, in chapter 10, of Jonathan Littell's novel The Kindly Ones (2006). Despite its subject matter, the novel's graphic representations of violence are of a kind not commonly found in Holocaust writing. Drawing on classical understandings of the ekphrastic genre, Berberich argues that The Kindly Ones uses ekphrasis in order to provide a perspective different from that found in traditional Holocaust writing and to solicit affective responses from its readers. By conjuring up images of the Holocaust - painful, brutal, uncomfortable - the novel forces the reader to look, to address the very thing, rather than just think about it as a euphemism or an abstraction. She concludes her reading with a discussion of the novel's ethical implications.

Finally, in the volume's final and eleventh chapter, Karin Sanders examines how a memoir by Jenny Diski, Skating to Antarctica (1997), tries to circumvent trauma by searching for a space of deliberate forgetfulness. Diski makes use of two central images: the first is the whiteness and ice connected with a trip to Antarctica, and the second is "Schrödinger's box" and the possibility of a superposition of states, which Sanders reads as a powerful literary metaphor for the suspension of knowledge about the key agent of Diski's trauma. Diski's memoir demonstrates how entrenched the concept of icescapes is as a blank space in our cultural imagination and how it can be used not only to represent mental distress and trauma but also to expand the perspective from individual to historical trauma. The essay shows how whiteness - as in the colors of walls, bed 
sheets, and ice - can be seen not only as a kind of non-image, an image of ultimate (albeit failed) forgetfulness, but also as a powerful mnemonic linked to trauma.

\section{Works cited}

Bal, Mieke (2002) Travelling Concepts in the Humanities: A Rough Guide (Toronto: University of Toronto Press)

Benjamin, Walter (1968) Illuminations. Edited by Hannah Arendt, translated by Harry Zohn (New York: Schocken Books)

Blanchot, Maurice (1995) The Work of Fire. Translated by Charlotte Mandell (Stanford: Stanford University Press)

Craps, Stef (2013) Postcolonial Witnessing: Trauma out of Bounds (Basingstoke: Palgrave Macmillan)

Culler, Jonathan (1988) Framing the Sign: Criticism and its Institutions (Oxford: Basil Blackwell)

Fassin, Didier and Richard Rechtman (2009) The Empire of Trauma: An Inquiry into the Condition of Victimhood (Princeton and Oxford: Princeton University Press)

Fischer, Barbara K. (2014) Museum Mediations: Reframing Ekphrasis in Contemporary American Poetry (London: Routledge)

Freud, Sigmund (1958) The Standard Edition of the Complete Psychological Works by Sigmund Freud, Vol. 12 (London: The Hogarth Press)

Hagstrum, Jean H. (1958) The Sister Arts: The Tradition of Literary Pictorialism and English Poetry from Dryden to Gray (Chicago: The University of Chicago Press)

Hartman, Geoffrey H. (1954) Unmediated Vision: An Interpretation of Wordsworth, Hopkins, Rilke and Valéry (New Haven: Yale University Press)

Heffernan, James A. W. (2004) Museum of Word: The Poetics of Ekphrasis from Homer to Ashbery (Chicago and London: The University of Chicago Press)

Lessing, Gotthold Ephraim (2003 [1766]) Laocoön: An Essay on the Limits of Painting and Poetry (Cambridge: Cambridge University Press)

Lund, Hans (1998) "Ekphrastic Linkage and Contextual Ekphrasis," in Valerie Robillard and Els Jongeneel (eds.), Pictures into Words: Theoretical and Descriptive Approaches to Ekphrasis (Amsterdam: VU University Press), pp. 173-188

Luckhurst, Roger (2008) The Trauma Question (London: Routledge)

Mitchell, W. J. T. (1994) Picture Theory: Essays on Verbal and Visual Representation (Chicago: The University of Chicago Press)

Mitchell, W. J. T. (2005) What Do Pictures Want? The Lives and Loves of Images (Chicago: The University of Chicago Press)

Mitchell, W. J. T. (2011) Cloning Terror: The War of Images, 9/11 to the Present (Chicago: The University of Chicago Press)

Morris, David (2016) The Evil Hours: A Biography of Post-traumatic Stress Disorder (New York: First Mariner Books)

Moxey, Keith (2008) "Visual Studies and the Iconic Turn," Journal of Visual Culture, 7.2, pp. 131-146 
Paul, Catherine E. (2002) Poetry in the Museums of Modernism: Yeats, Pound, Moore, Stein (Ann Arbor: University of Michigan Press)

Shklovsky, Viktor (1965) “Art as Technique," in Lee T. Lemon and Marion J. Reis (eds.), Russian Formalist Criticism: Four Essays (Lincoln: University of Nebraska Press), pp. $5-24$

Webb, Ruth (1999) "Ekphrasis Ancient and Modern: The Invention of a Genre," Word \& Image, 15.1, pp. 7-18

Wittgenstein, Ludwig (1958) Philosophical Investigations. Translated by G. E. M. Anscombe (Oxford: Basil Blackwell)

Wittgenstein, Ludwig (1969) On Certainty. Translated by Denis Paul and G. E. M. Anscombe, edited by G. E. M. Anscombe and G. H. von Wright (New York: J. \& J. Harper Editions)

Wordsworth, William (2002) "Preface to Lyrical Ballads," in Duncan Wu (ed.), Romanticism: An Anthology. Fourth edition (Oxford: Wiley-Blackwell), pp. 506-518 
